\title{
The Innovation Strategy Research of College Students Ideological and Political Education based on the Campus Network Environment
}

\author{
Dong ZHONG* \\ School of electronic and information, Hubei University of Science and Technology, Xianning \\ 437100, China \\ zhongdong0129@163.com
}

\begin{abstract}
Keywords: Campus Network Environment, Ideological and Political Education, College Students.
\end{abstract}
\begin{abstract}
Based on the analysis of contemporary college students' ideological characteristics, the current situation of College Students' Ideological and Political Education under the environment of campus network has been analyzed in the paper. What's more, the positive and negative effects on campus network of College Students' Ideological and political education has also been researched. Based on the campus network environment countermeasures, enhance the effectiveness of ideological and political education of college students, explore the innovation strategy of college students ideological and political education the work.
\end{abstract}

\section{Introduction}

With the development of computer and network technology, network era can generate some significant changes on people's way of life, way of thinking, and social behavior. Especially the rapid development of the campus network, and gradually perfect[1]. Outlook of college students, promote academic, access to information, exchange ideas[2]. At the same time to enhance the actual effect of ideological and political education, it can also produce significant negative impact on college students' values, outlook on life, morality, ideology and behavior[3]. It can bring severe challenges on college students' ideological and political education work .

On the one hand, put forward many new changes to the traditional ideological and political education, it is urgent to study the ideological and political educational of campus network environment, to look at the ideological and political education subject from a new angle, the practical theory research results to improve the ideological and political education[4]. As a kind of thought the political education carrier, in order to meet the needs of the era of information network development, especially in Colleges and universities should strengthen the construction of network ideological and political education[5], pay attention to the campus network in college students' Ideological and political education in the important role, strengthening the theoretical research and practical exploration, improve the efficiency and quality of the ideological and political work in Colleges and universities[6]. Therefore development has important theoretical significance the ideological and political education of College Students under the campus network environment based on.

The traditional ideological and political education put forward many new challenges, the urgent need for campus network environment research in ideological and political education, the 
ideological and political education from a new perspective view, realistic theoretical research results to improve the ideological and political education work[7][8]. Network as a kind of ideological and political education carrier, in order to adapt to the needs of the development of information network era, especially in colleges and universities should strengthen the construction of the network ideological and political education[9], pay attention to play to the campus network plays an important part in college students' ideological and political education work[10], strengthen the theoretical research and practical exploration, improve the efficiency and quality of ideological and political work. So to carry out the ideological and political education based on campus network environment has important theoretical significance.

On the other hand, the campus network is the carrier of the network culture, give full play to the management of campus network, service, education, enrich the students' Ideological and political education content, expand its channels, improve the method, workers become the ideological and political education of college students and the whole society are very concerned about the problem. To strengthen the construction of campus culture and promoting the ideological and political the times are required to carry out education of Ideological and political education of College Students under the campus network environment based on.

\section{Analysis on the current situation of Ideological and political education of College Students under the network environment}

Study on the ideological and Political Education under the network environment, mainly concentrated in the field of foreign network ethics problems, mainly involves the following aspects of Internet use and operation of the process, including the specification of the network, the network behavior of the specific nature of the definition, research on the specific problems in the network. The network and other related the social phenomenon and the emergence of cross linked problems, including the social structure, the network caused by the cultural exchanges, economy, democratic system changes and other issues. On the problems caused by the network moral problems, including the analysis of theories of network ethics, to explain the theory of ecological network. The original moral ethics in the applicability of the network behavior problems. Since China officially opened with the line connection, represented by the Internet information network technology With the trend of rapid development, are widely applied to various fields of social life, cause the whole social production, profound changes in the way of life.

In the field of Ideological and political education of the school, take the network as the carrier, high degree of attention and widespread concern and Research on network effects is also carried out by all walks of life. In the academic circles, Zhang Jiansong in the play "the role of" campus network in Ideological and political work in an article first proposed the concept of "network ideological and political work", he believes that "the ideological and political work, generally speaking, is to use the campus network to carry out ideological and political work on students, kicked off the research of network ideological and political education.

The current research on the thought of the political education of College Students under the network environment is not deep enough. Mainly in the following aspects of the ideas of the people under the network environment gradient do not pay enough attention to the network environment Analysis of idea and behavior mode of college students in-depth, comprehensive study of network ideological and political education for college students to practice less on the network environment research influence on College Students' ideology is not enough. 


\section{The Innovation Strategy Research of College Students' Ideological and Political Education based on the Campus Network Environment}

The innovation strategy of campus network based on Ideological and political education of college students, to explore the use of the advantages of the campus network, make students realize the ideological and political education network, scientific and systematic. Through the concept of innovation, to develop college students' Ideological and political education, resource library network, actively develop the ideological and political education software, the establishment of the parent and student cooperative the interactive platform, the establishment of the campus network supervision interaction mechanism, emergency system and other aspects of the establishment of College Students' network emergency research innovation strategy.

The purpose of this article is to study the innovation strategy of Ideological and political education based on campus network environment, centered on the problem, according to the spirit of the relevant documents on strengthening the network construction and management of Marx the basic principle of Marxism and the central, according to the research results of the ideological and political education, from two aspects of theory and practice, explore Analysis of the influence of campus network on the ideological and political education, strengthen the innovation strategy of Ideological and political education focuses on the campus network environment, highlighting the use of theories and methods, and the innovation of Ideological and political education, to play a leading role in the campus network, guide the students to better adhere to the socialist core value system, construction of network education an effective platform of campus network, to create a good educational environment. I hope through analysis and research of this topic, causing workers ideological and political education of college students on the issue of further attention and exploration, but also hope that through this study, some college students' ideological and political education is worth learning results from theory and practice.

\section{(1)To set up an open concept of ideological and political education}

The constructivist view of teacher that the teacher is to help the construction of meaning, facilitator, rather than knowledge providers and students. Under the network environment, the information flow in the traditional sense of the campus has been unable to stop the raging and closed morality environment no longer exist. We must establish the concept of Ideological and political education globalization and take the initiative to meet the challenges, and actively guide students to actively construct their significance. To take the initiative to change the past be inopportune or inappropriate education mode, make full use of the network to expand education, out of regional consciousness.

(2) make full use of, first and so on modern communication means to carry out education Under the network environment, the University of communication between teachers and students is becoming more and more openness and equality, the ideological and political education workers and students can pass, hot, free discussion and exchange of ideas and difficult problems. In the use of colleges and universities to carry out ideological and political education in the network, one is to note that the public opinion, a good grasp of the timeliness of the timely processing of information of public opinion positive, positive guidance of network public opinion, the equality of equal dialogue and action to understand people with emotion four basic principles.

(3) Actively promote the use of multimedia teaching, to achieve the modernization of Ideological and political theory teaching means

The actual effect of ideological and political theory course teaching depends largely on the ways and means of innovation. Under the network environment, the ideological and political theory course teaching should make full use of the network the modern means. Use of the campus network 
system, constructs the online ideological and political theory course teaching base, such as online set theory misgivings, information query, hot discussion, case analysis, simulation test, and other functions, to achieve resource sharing, promote the improvement of theoretical teaching effect.

(4) the establishment of the campus network of teachers and students interaction platform The opening of Interactive Mail, micro-blog group, mobile phone, mail and other interactive courses, further close the relationship between teachers and students, the campus construction of harmonious interpersonal atmosphere, make the teacher really play a role. Through the interactive platform for teachers and students, we further strengthen the moral education, so that teachers can bear high duty teaching fully. The use of interactive platform for teachers and students to carry out ideological education, earnestly implement the management in the daily education of students in their functions.

\section{Summary}

To carry out ideological and political education of College Students under the campus network environment based on the theory for perfecting the system of Ideological and political discipline, promote physical and mental health of the students, all-round development, has important theoretical significance and practical significance to maintain social stability.

\section{Acknowledgment}

The authors gratefully acknowledge the financial support for this work provided by the Party building and ideological and political education scientific research project of Hubei University of science and technology No. 2016-17Xdj13 and the science research project in Hubei province department of education, Grant No. B2015077, the National Natural Science Foundation of China (NSFC) under the Grant No. 61575148, the teaching reform program of Hubei University of science and technology, No. 2015-XA-007.

\section{References}

[1] Yuan Guiren, to promote the ideological and political education in Colleges and universities into the network, China's higher education. 2(2002)23-26.

[2] Li Yaohu, the influence of the Internet on the ideological and political work in Colleges and universities, the social science of Nanjing University of Aeronautics \& Astronautics. 1(2015)32-35.

[3] Chen Chunping, Current contents and methods of College Students' network moral education, Guangxi social science. 1(2016)56-59.

[4] Gao Richen, Strategy, innovation of Ideological and political education of College Students under the network environment of the journal.5( 2010)71-74.

[5] LuYang, Innovative research on Ideological and political education of College Students under new media environment, Liaoning Normal University, master's thesis, 8(2011)10-16.

[6] Xu Zhengxiang, New media literacy: the important content of the ideological and political education of college students. Heilongjiang Education (higher education research and evaluation).11( 2008 )89-92. 
[7] Xiong Shuping, Research on the ideological and political education of College Students under the new media environment. Hunan University( 2012)

[8]Cao Haijuan, The innovation of Ideological and political work in Colleges and universities in the whole media era. Capital University of Economics and Business (2012)

[9] Lei Xiaopeng, The study of humanistic care of College Students' Ideological and political education. Chongqing Normal University (2016)

[10] Li Haiqing, On the influence of We Chat on the ideological and political education of college students. North Central University (2016) 